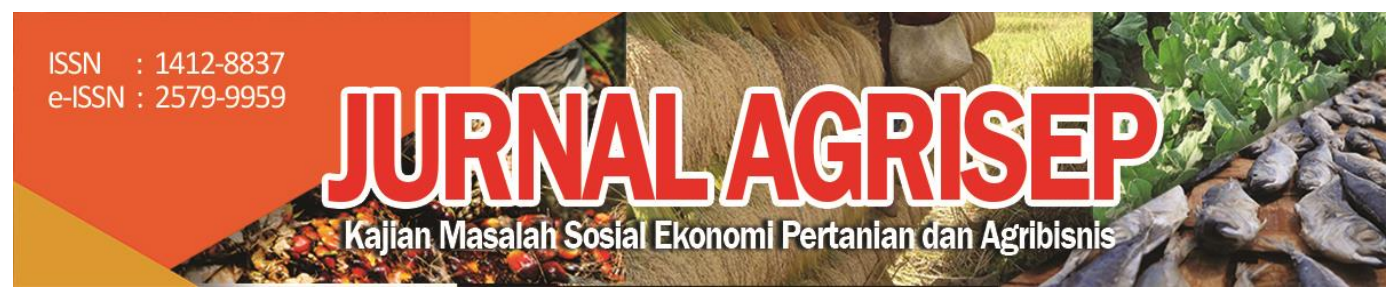

DOI: 10.31186/jagrisep.20.1.25-40

\title{
PENGGUNAAN TELEPON SELULER UNTUK PEMASARAN SERTA DAMPAKNYA TERHADAP KESEJAHTERAAN PETANI
}

\author{
The Use of Celluler Phones for Marketing and its Impact on the Welfare \\ of Farmers \\ Feryanto $\bigotimes_{1)}$; Nia Rosiana ${ }^{1)}$ \\ ${ }^{1)}$ Departemen Agribisnis, Fakultas Ekonomi dan Manajemen, Institut \\ Pertanian Bogor \\ Email: feryanto.ipb@apps.ipb.ac.id
}

\begin{abstract}
The development of information technology has encouraged farmers to be able to use cellular phones to support agricultural activities. However, only a few farmers use their cellphones for marketing activities. This study aims to analysis factors influence farmers to use cell phones in marketing activities, and whether cell phone use has an impact on farmers' welfare. The analytical method used is the logit regression model and Propensity Score Matching (PSM). The results showed that what influenced farmers' decisions to use cellular phones for marketing activities were gender, marital status, number of adult household members, education, land ownership status, land area, and counseling. Meanwhile, the impact of the use of cellular telephones, shows that the average farm farmers receive higher treatment compared to the control farmers group.
\end{abstract}

Keywords : farmers, marketing, mobile phone, Propensity Score Matching (PSM), welfare

\section{ABSTRAK}

Perkembangan teknologi informasi telah mendorong petani untuk dapat memanfaatkan telepon seluler untuk mendukung aktivitas pertaniannya. Namun demikian masih sedikit petani yang memanfaatkan telepon selulernya untuk kegiatan pemasaran. Penelitian ini bertujuan untuk menganalisis faktor-faktor apa saja yang memengaruhi petani untuk menggunakan telepon seluler dalam kegiatan pemasaran, dan apakah penggunaan telepon seluler memiliki dampak terhadap kesejahteraan petani. Metode analisis yang digunakan adalah model regresi logit dan Propensity Score 
Matching (PSM). Hasil penelitian menunjukkan bahwa yang memengaruhi keputusan petani menggunakan telepon seluler untuk kegiatan pemasaran adalah jenis kelamin, status pernikahan, jumlah anggota rumah tangga dewasa, pendidikan, status kepemilikan lahan, luas lahan, dan penyuluhan.Sementara itu, dampak penggunaan telepon seluler, menunjukkan bahwa rata-rata penerimaan usahatani kelompok petani treatment lebih besar bila dibandingkan kelompok petani kontrol.

Kata Kunci : kesejahteraan, pemasaran, petani, propensity score matching (PSM), telepon seluler

\section{PENDAHULUAN}

Kemudahan dalam mengakses dan mendapatkan informasi saat ini merupakan suatu keharusan bagi petani. Hal ini terkait dengan proses keputusan yang akan diambil petani, termasuk kegiatan budidaya yang akan dilakukan, penyediaan input, permodalan bahkan sampai kepada kegiatan pasca panen dan pemasaran. Dengan keterbatasan teknologi informasi yang dikuasai oleh petani, terutama dikalangan pedesaan menyebabkan petani seringkali secara langsung harus berpergian mencari informasi-informasi tersebut. Selain itu asimetri informasi yang terjadi menyebabkan petani dalam kondisi pihak yang selalu dirugikan, akibat lemahnya posisi tawar karena ketidaktahuan perkembangan informasi dan harga yang terjadi dipasar. Kondisi ini dialami hampir seluruh petani, termasuk petani padi atau tanaman pangan yang jumlahnya lebih dari 20,28 juta rumah tangga. Kondisi ini tentunya tidak sesuai dengan perkembangan teknologi informasi yang semakin maju, dimana perkembangan teknologi informasi seharusnya bisa mengatasi masalah klasik yang dihadapi oleh petani kecil dan berada di daerah.

Kementerian Komunikasi dan Informasi (Kemenkominfo) pada tahun 2015 menyebutkan bahwa kepemilikan dan akses petani terhadap teknologi informasi dan komunikasi (TIK) sangat rendah sekali, yakni hanya 7,2 persen. Disamping itu petani yang menggunakan internet baru sebesar 13,44 persen dari total petani. Rendahnya pemanfaatan teknologi informasi di petani dan di perdesaan di duga terbatasnya infrastruktur dan kurangnya pengetahuan masyarakat petani untuk memanfaatkan fitur-fitur yang terdapat di perangkat komunikasi yang dimilikinya, salah satunya telepon seluler (Prayoga, 2014). Saat ini telepon seluler merupakan salah satu media dalam pemanfaatn TIK. Arus teknologi menjadikan handphone bukan lagi menjadi barang asing dan mewah bagi masyarakat Indonesia termasuk petani. Saat ini, petani yang telah memiliki telepon seluler mencapai 66,8 persen (Kemkominfo, 2015).

Penggunaan telepon seluler atau telepon pintar di pedesaan dan khususnya petani baru sebatas alat komunikasi dan hiburan. Telepon genggam belum dioptimalkan untuk dimanfaatkan mendukung kegiatan usahatani dan kegiatan pasca panen. Namun demikian penggunaan telepon seluler atau 
telepon pintar hanya sebatas alat komunikasi dan hiburan di perdesaan dan khususnya petani. Sebagian kecil petani tersebut mengakses internet melalui telepon seluler yang dimiliki untuk mencari informasi pertanian. Telepon seluler digunakan sebagai media untuk melakukan aktivitas penyediaan input dan pemasaran hasil pertanian. Namun demikian, Prayoga (2017) menunjukkan bahwa aktivitas pencarian informasi pasar dan jual beli untuk aktivitas pemasaran melalui penggunaan telepon seluler dan internet masih rendah. Meskipun demikian, pemanfaatan internet dapat mempermudah petani dalam memasarkan hasil pertanian yang mendorong pada peningkatan pendapatan petani melalui peningkatan nilai jual (Yuantari et al., 2016).

Pemanfaatan telepon seluler sebagai media komunikasi dan pencarian informasi diharapkan dapat mengatasi asimetri informasi yang sering terjadi dan dialami petani, terutama dalam memasarkan hasil pertaniannya. Selain itu penggunaan telepon seluler juga bermanfaat dalam mengatasi dan menjembatani kesenjangan antara kesediaan dan pengiriman input pertanian dan infrastruktur pertanian (Jensen, 2010; Mittal dan Mehar, 2012; Khan et al., 2019). Selain itu, dapat mendukung proses pengambilan keputusan yang meningkatkan produktivitas dan ketahanan pangan rumah tangga (Soedarto dan Hendrarini, 2019).

Beberapa penelitian terdahulu menyebutkan bahwa telepon seluler memberikan dampak positif pada kegiatan usahatani dan kesejahteraan petani. Hal ini dapat dikonfirmasi dari adanya peningkatan hasil dan produktivitas (Lio and Liu, 2006; Gandhi and Tripathi, 2010; Fafchamps and Minten, 2012). Pada kegiatan pemasaran Jensen (2007) dan Aker and Fafchamps (2013) menunjukkan bahwa penggunaan telepon seluler memberikan efisiensi baik bagi petani sebagai porodusen dan konsumen, karena mengurangi disparitas dan asimetri informasi, serta mempercepat aktivitas logistik. Disamping itu, pemanfaatan telepon seluler sebagai media untuk penggunaan internet dapat membuka pasar global hingga ke konsumen dan produsen berpeluang untuk mendapatkan keputusan pemasaran dan akses harga yang lebih baik serta meningkatkan posisi tawar dan keunggulan kompetitif (Holden, Shiferaw, \& Pender, 2001; Tadasse \& Bahiigwa, 2015; Sutisna 2018). Berkenaan dengan hal tersebut, paper ini bertujuan untuk (1) menganalisis faktor-faktor apa yang memengaruhi keputusan petani dalam menggunakan telepon seluler sebagai media untuk kegiatan pertanian terutama memasarkan hasil pertanian, dan (2) bagaimana dampak penggunaan telepon seluler terhadap kesejahteraan petani.

\section{METODE PENELITIAN}

\section{Data Penelitian}

Penelitian ini menggunakan data Indonesia Family Life Survey (IFLS) atau Survei Aspek Kehidupan Rumah Tangga Indonesia (Sakerti) gelombang 
terakhir - Tahun 2014 (IFLS 5). IFLS merupakan survey longitudinal di bidang sosial-ekonomi dan Kesehatan. Survei ini dilaksanakan oleh RAND Corporation terhadap sampel yang mewakili 83 persen populasi penduduk Indonesia di 13 propinsi (Strauss et al, 2009). Survey yang dilakukan dengan mengumpulkan data pada level individu, rumah tangga dan sampai komunitas terkecil tempat individu dan rumah tangga berada. IFLS pertama dilakukan pada tahun 1993, dan dilanjutkan pada tahun 1997, 1998, 2000, dan 2007. Sementara survey gelombang terakhir (data terbaru) untuk mendapatkan IFLS 5 dilakukan pada tahun 2014, dimana berhasil diwawancarai total rumah tangga sebanyak 15.000 dan 50.000 individu.

Data IFLS sangat relevan digunakan dalam penelitian ini, dikarenakan informasi yang dibutuhkan untuk penelitian ini tersedia dan merupakan survei data rumah tangga atau keluarga terlengkap di Indonesia. Sampel rumah tangga petani yang digunakan adalah petani tanaman padi yang berjumlah 1.557. Dimana 17,7 persen (276 petani) yang menggunakan telepon seluler untuk kegiatan pertanian dan pemasaran hasil yang selanjutnya merupakan sebagai kelompok treatment. Sementara 82,3 persen (1.281 petani) belum atau tidak menggunakan telepon selulernya untuk mendukung kegiatan pertanian (termasuk pemasaran) dan selanjutnya disebut sebagai kelompok control. Data yang digunakan merupakan data cross-section, yakni IFLS Gelombang 5 tahun 2014.

\section{Metode Analisis Data}

\section{Regresi Logit Biner}

Keputusan petani apakah menggunakan telepon seluler atau tidak untuk kegiatan aktivitas pertanian, termasuk pemasaran hasil pertanian menggunakan pendekatan model regresi logit binner. Pada model logit binner, keputusan petani menggunakan telepon seluler untuk kegiatan pertanian, termasuk pemasaran hasil pertanian bernilai 1, sementara yang tidka menggunakan diberi nilai 0 . Secara matematis model fungsi logit untuk melihat keputusan petani, dapat dituliskan secara umum mengembangkan model yang digunakan oleh Etwire et al (2017),

$$
P_{i}=\ln \left(\frac{P_{i}}{1-P_{i}}\right)=a+b_{1} X_{1 i}+b_{2} X_{2 i}+\cdots+b_{14} X_{14 i}+e_{i}
$$

dimana $P_{i}$ merupakan variabel dummy keputusan petani dalam menggunakan telepon selulernya untuk kegiatan pemasaran pertanian dan aktivitas lain. Selain itu variabel bebas yang diduga memengaruhi petani untuk menggunakan telepon selulernya, terdiri dari 14 variabel bebas, diantaranya adalah; $\mathbf{X}_{\mathbf{1}}$ (umur), $\mathbf{X}_{2}$ (dummy jenis kelamin, pria $\left.=1\right), \mathbf{X}_{3}$ (dummy status pernikahan, menikah=1), $\mathbf{X}_{4}$ (jumlah anggota keluarga, satuan orang), $\mathbf{X}_{5}$ (jumlah anggota rumah tangga dewasa, satuan orang), $\mathbf{X}_{6}$ (pendidikan, satuan tahun), $\mathbf{X}_{7}$ ( dummy status 
kepemilikan lahan, milik=1), $\mathbf{X}_{\mathbf{8}}\left(\right.$ luas lahan, log harga), $\mathbf{X}_{\mathbf{9}}$ (harga gabah, log harga), $\mathbf{X}_{\mathbf{1 0}}$ (dummy irigasi, ya=1), $\mathbf{X}_{\mathbf{1 1}}$ (dummy penyuluhan, ya=1), $\mathbf{X}_{\mathbf{1 2}}$ (dummy desa, desa=1), $\mathbf{X}_{13}$ (dummy Jawa, Jawa $=1$ ), dan $\mathbf{X}_{14}$ merupakan dummy interaksi desa_jawa (rumah tangga yang berada di desa dan Pulau Jawa bernilai 1).

\section{Propensity Score Matching (PSM) dengan Pendekatan Average Treatment on Treated (ATT)}

PSM merupakan salah satu teknik pendugaan atau estimasi yang berusaha mengevaluasi suatu program atau intervensi dengan berusaha membentuk kelompok kontrol yang semirip mungkin dengan kelompok partisipan (treatment), berdasarkan karakteristik yang diamati (Khandker et al, 2010; Gertler et al, 2011). Desain pada penelitian ini adalah, kelompok partisipan (treatment) adalah petani yang menggunakan telepon selulernya untuk kegiatan pertanian, khususnya pemasaran. Sementara kelompok kontrol adalah petani yang tidak menggunakan telepon selulernya untuk kegiatan pertanian dan khususnya pemasaran hasil. Masalah umum dan mendasar yang sering dijumpai saat menggunakan PSM adalah tidak dapat mengukur potensi outcome dari rumah tangga yang menggunakan telepon seluler $\left(Y_{1 i}\right)$ dengan kelompok kontrol $\left(Y_{0 i}\right)$ pada waktu yang bersamaan. Sehingga hanya salah satu saja diantara keduanya yang bisa diamati, maka yang digunakan adalah model estimasi yang memungkinkan untuk melihat nilai rata-rata dampak penggunaan telepon seluler tersebut. Metode ini disebut dengan pendekatan Average Treatment on Treated (ATT). Model estimasi PSM dengan menggunakan pendekatan ATT dapat mengestimasi nilai rata-rata dari rumah tangga petani yang menggunakan telepon seluler ataupun tidak. Model ATT dapat ditulis sebagai berikut (Khandker et al, 2010; Gertler et al, 2011);

$$
\mathrm{ATT}=\mathrm{E}\left[\mathrm{Y}_{1 \mathrm{i}} \mid \mathrm{D}_{\mathrm{i}}=1\right]-\mathrm{E}\left[\mathrm{Y}_{0 \mathrm{i}} \mid \mathrm{D}_{\mathrm{i}}=0\right]
$$

Dimana ATT merupakan dampak yang dihitung dari variabel outcome (penerimaan usahatani) yang diestimasi dari hasil rumah tangga petani yang menggunakan telepon seluler, yakni $\mathbf{E}\left[\mathbf{Y}_{1 \mathrm{i}} \mid \mathbf{D}_{\mathbf{i}}=1\right]$ dikurangi dengan rumah tangga yang tidak menggunakan telepon seluler, $\mathbf{E}\left[\mathbf{Y}_{0 \mathrm{i}} \mid \mathbf{D}_{\mathbf{i}}=\mathbf{0}\right]$.

Melalui pendekatan PMS ini dapat mengurangi bias dalam pengambilan keputusan akibat adanya potensial heterogeneity dan cofounding. Pengaruh cofounding dalam penelitian ini berpotensi memperbesar atau memperkecil hubungan sebenarnya antar kelompok yang diamati. Sehingga kurang tepat membandingkan hasil secara langsung, karena dapat memberikan kesimpulan yang salah. Untuk mengatasi masalah tersebut akan digunakan Kernel Matching dan Nearest Neighbor Matching pada teknis estimasi ATT. Kedua metide ini merupakan yang umum digunakan, dimana metode Kernel Matching, setiap rumah tangga yang menjadi kelompok treatment dicocokkan dengan bobot ratarata tertimbang dari rumah tangga kontrol. Sementara pada metode Nearest Neighbor Matching, tujuan utamanya adalah meminimalkan perbedaan mutlak 
skor kecenderungan yang diperkirakan (estimated propensity score) antara kelompok treatment dengan kelompok kontrol.

\section{HASIL DAN PEMBAHASAN}

Berdasarkan Tabel 1, dapat diuraikan mengenai deskripsi data secara statistik dari variabel yang digunakan dalam penelitian ini. Secara statistik dapat dilihat bahwa rata-rata jumlah penerimaan usahatani padi dari seluruh sampel petani adalah sebesar Rp. 14,61 juta rupiah selama satu tahun dimana penerimaan usahatani padi rumah tangga yang menggunakan telepon seluler untuk kegiatan usahatani dan pemasaran hasil pertaniannya lebih besar bila dibandingkan dengan rumah tangga yang tidak menggunakan telepon seluler. Sementara variabel lain menunjukkan bahwa rata-rata umur petani secara keseluruhan diantara 54-55 tahun, dengan rata-rata jumlah anggota keluarga sebanyak dewasa yang membantu kegiatan usahatani sekitar 4 orang, dan ratarata lama pendidikan formal yang ditempuh petani hanya 6-7 tahun, artinya pendidikan petani didominasi dengan pendidikan dasar. Bila dibandingkan antara kelompok petani treatment dan kontrol, lama pendidikan formal yang ditempuh menunjukkan kelompok treatment lebih lama menempuh pendidikan formal (7-8 tahun), bila dibandingkan dengan kelompok kontrol yang hanya sekitar 5-6 tahun saja. Pendidikan petani yang baik akan berkorelasi positif dengan cara berpikir dan wawasan, sehingga akan mudah menerima hal-hal baru.

Sementara itu dari luas lahan yang dimiliki rata-rata dari seluruh sampel rumah tangga, memiliki luas lahan sebesar $4.158 \mathrm{~m}^{2}$, dimana rata-rata luas lahan kelompok treatment lebih besar hampir dua kali dari rata-rata luas lahan yang dimiliki oleh kelompok kontrol yang hanya seluas $3.720 \mathrm{~m}^{2}$. Sedangkan dari rata-rata harga gabah yang diterima oleh seluruh petani sepanjang tahun 2014 adalah sebesar Rp. 3.648 per kg. Jika membandingkan dua kelompok (treatment dan kontrol), tidak terlihat perbedaan yang signifikan.

Berdasarkan uji beda rata-rata antara kedua kelompok (treatment dengan kontrol), secara statistik sebelum melakukan matching dengan teknik PSM menunjukkan bahwa kedua kelompok responden secara umum memiliki perbedaan yang signifikan secara rata-rata (means). Variabel-variabel yang berdasarkan nilai t-test memiliki perbedaan yang signifikan adalah; penerimaan usahatani, umur, jenis kelamin, jumlah anggota rumah tangga dewasa, pendidikan, status kepemilikan lahan, luas lahan, dan program penyuluhan yang diikuti (secara rinci dapat diihat pada Tabel 1).

30 | Feryanto dan Nia Rosiana; Penggunaan Telepon Seluler ... 
Tabel 1 Deskriptif Statistik Sampel Rumah Tangga Petani

\begin{tabular}{|c|c|c|c|c|c|c|c|}
\hline \multirow{2}{*}{$\begin{array}{c}\text { Variabel } \\
(1) \\
\end{array}$} & \multicolumn{2}{|c|}{ Total Sampel } & \multicolumn{2}{|c|}{$\begin{array}{c}\text { Petani Yang } \\
\text { Menggunakan } \\
\text { Telepon Seluler } \\
\text { (Treatment) } \\
\end{array}$} & \multicolumn{2}{|c|}{$\begin{array}{c}\text { Petani Yang Tidak } \\
\text { Menggunakan } \\
\text { Telepon Seluler } \\
\text { (Control) } \\
\end{array}$} & \multirow{2}{*}{$\begin{array}{c}\text { Mean } \\
\text { Diff\# } \\
(8)=(5)-(7)\end{array}$} \\
\hline & $\begin{array}{c}\text { Mean } \\
(2) \\
\end{array}$ & $\begin{array}{l}\text { Sd.Dev } \\
(3)\end{array}$ & $\begin{array}{c}\text { Mean } \\
(4)\end{array}$ & $\begin{array}{l}\text { Sd.Dev } \\
(5)\end{array}$ & $\begin{array}{c}\text { Mean } \\
(6)\end{array}$ & $\begin{array}{c}\text { Sd.Dev } \\
(7)\end{array}$ & \\
\hline \multicolumn{8}{|l|}{ Penerimaan } \\
\hline $\begin{array}{l}\text { Usahatani } \\
\text { (Rp.000) }\end{array}$ & 14.610 & 10.870 & 18.400 & 12.190 & 9.248 & 9.132 & $9.152 * * *$ \\
\hline Umur (Tahun) & 54,41 & 13,31 & 51,86 & 13,44 & 54,96 & 13,22 & $-3,1^{* * *}$ \\
\hline Pria (Dummy) & 0,896 & 0,305 & 0,931 & 0,253 & 0,888 & 0,315 & $0,043^{* *}$ \\
\hline $\begin{array}{l}\text { Menikah } \\
\text { (Dummy) }\end{array}$ & 0,878 & 0,327 & 0,895 & 0,397 & 0,874 & 0,331 & 0,021 \\
\hline $\begin{array}{l}\text { Jumlah Anggota } \\
\text { RT Dewasa } \\
\text { (Orang) }\end{array}$ & 4,064 & 1,690 & 4,333 & 1,672 & 4,005 & 1,689 & $0,328 * *$ \\
\hline $\begin{array}{l}\text { Jumlah Anggota } \\
\text { Keluarga } \\
\text { (Orang) }\end{array}$ & 5,480 & 2,608 & 5,37 & 2,664 & 5,504 & 2,596 & $-0,134$ \\
\hline $\begin{array}{l}\text { Lama } \\
\text { Pendidikan } \\
\text { (Tahun) }\end{array}$ & 6,083 & 4,150 & 7,772 & 4,431 & 5,719 & 3,996 & $2,053^{* * *}$ \\
\hline $\begin{array}{l}\text { Status } \\
\text { Kepemilikan } \\
\text { Lahan (Dummy) }\end{array}$ & 0,362 & 0,481 & 0,420 & 0,391 & 0,35 & 0,321 & $0,07^{* *}$ \\
\hline Luas tanam $\left(\mathrm{M}^{2}\right)$ & 4.158 & 5.056 & 6.189 & 5.797 & 3.720 & 3.542 & $2.469^{* * *}$ \\
\hline Irigasi (dummy) & 0,503 & 0,500 & 0,500 & 0,489 & 0,504 & 0,500 & $-0,004$ \\
\hline Harga (Rp) & 3.648 & 853,2 & 3.699 & 884,13 & 3.637 & 846,35 & 62 \\
\hline $\begin{array}{l}\text { Penyuluhan } \\
\text { (Dummy) }\end{array}$ & 0,502 & 0,500 & 0,435 & 0,410 & 0,516 & 0,499 & $-0,081^{* *}$ \\
\hline Observasi (n) & & 1.557 & & 276 & & 1281 & \\
\hline
\end{tabular}

Keterangan:

\# $\quad$ : menggunakan t-statistik untuk melihat signifikansi

** $\quad$ : signifikan pada tingkat kepercayaan (level of confidence) $=95 \%($ alpha $=5 \%)$

*** $\quad$ : signifikan pada tingkat kepercayaan (level of confidence) $=99 \%($ alpha $=1 \%)$

Sumber: Hasil Olahan Data Primer, 2020

\section{Faktor-Faktor yang Memengaruhi Petani dalam Menggunakan Telepon Seluler untuk Kegiatan Pemasaran Hasil Pertanian}

Pada bagian ini akan disampaikan analisis faktor-faktor yang memengaruhi keputusan petani dalam menggunakan telepon seluler yang mereka miliki untuk kegiatan pertanian, khususnya pemasaran hasil pertanian. Analisis akan dilihat dari total sampel rumah tangga yang digunakan dalam penelitian ini, dan rumah tangga yang berada di Pulau Jawa dan di luar Pulau Jawa. Dis-agregasi dilakukan dengan pertimbangan infrastruktur teknologi informasi di Pulau Jawa relatif lebih maju bila dibandingkan dengan di luar 
Jawa, sehingga relevan untuk melihat perbandingan keputusan petani dalam menggunakan telepon selulernya untuk kegiatan pemasaran hasil pertanian.

Berdasarkan hasil pendugaan dengan menggunakan model logit pada seluruh rumah tangga petani padi (total sampel), diperoleh bahwa variabel jenis kelamin, status pernikahan, jumlah anggota rumah tangga dewasa, pendidikan, status kepemilikan lahan, luas lahan, dan penyuluhan yang diterima petani memberikan pengaruh positif dan signifikan secara statistik terhadap petani padi menggunakan telepon selulernya untuk kegiatan pemasaran hasil. Kegiatan pemasaran dilakukan dengan menggunakan layanan panggilan telepon, sms, dan aplikasi media sosial lainnya yakni whastapp, dan facebook. Variabel status pernikahan memberikan pengaruh positif dan siginifikan bagi petani untuk menggunakan telepon selulernya sebagai media untuk memasarkan. Status pernikahan mendorong petani untuk memiliki telepon seluler agar dapat berkomunikasi dengan anggota keluarga, sekaligus dimanfaatkan sebagai media untuk memasarkan hasil pertaniannya. Sama halnya dengan variabel status pernikahan, variabel anggota rumah tangga dewasa memberikan pengaruh positif kepada petani untuk menggunakan telepon selelurnya, hal ini dimungkinkan awalnya untuk memudahkan komunikasi antar anggota rumah tangga. Namun dalam perkembangannya telepon seluler digunakan untuk kegiatan usahatani, terutama mencari informasi tentang harga gabah petani dan mencari pembeli. Anggota rumah tangga dewasa juga mampu memberikan pengaruh dalam hal ini, karena kemampuan anak-anak muda yang relatif lebih peka dan adaptif terhadap perkembangan teknologi informasi (Kemenkominfo, 2015).

Tingkat pendidikan yang diukur dari lama pendidikan formal yang ditempuh memiliki peluang dan pengaruh lebih besar dan positif alam memengaruhi keputusan petani. Artinya semakin tinggi pendidikan akan mendorong petani menggunakan telepon seluler untuk memasarkan hasil pertaniannya. Hal ini sesuai dengan temuan Ferrer et al (2003) yang menyatakan bahwa terdapat hbungan positif antara pendidikan petani dengan penggunaan internet dan telepon seluler. Hal ini mengindikasikan bahwa pendidikan memberikan wawasan kepada petani untuk mendapatkan informasi lebih banyak untuk mendukung kegiatan pertaniannya.

Variabel status kepemilikan lahan dan luas lahan yang dimiliki berpengaruh signifikan bagi petani untuk menggunakan telepon seluler dalam kegiatan pemasarannya. Hal ini menunjukkan bahwa semakin luas lahan yang diusahakan dan merupakan milik sendiri akan mendorong petani dalam menggunakan telepon selulernya untuk kegiatan pemasaran hasil pertanian. Pertimbangan yang dimiliki petani adalah semakin luas lahan yang diusahakan akan menghasilkan gabah yang lebih banyak, sehingga diperlukan kepastian pasar dan harga untuk menjamin petani tidak mengalami kerugian dalam memasuki musim panen. Petani dapat menggunakan telepon selulernya untuk 
menghubungi pembeli (penggilingan padi) yang telah menjadi pelanggan atau pembeli baru untuk dapat membandingkan harga. Melalui telepon seluler memudahkan petani untuk memilih pembeli atau pasar yang memberikan kepastian harga dan pasar yang lebih menguntungkan (Mittal and Mehar, 2012). Namun demikian, hasil ini berbeda dengan temuan Donkor et al (2018) yang menunjukkan bahwa luas lahan yang diusahakan tidak memiliki pengaruh terhadap keputusan petani dalam melakukan kegiatan pemasarannya.

Tabel 2 Hasil Estimasi yang Memengaruhi Petani Padi dalam Menggunakan Telepon Seluler untuk Kegiatan Pemasaran Hasil Pertanian

\begin{tabular}{|c|c|c|c|c|c|c|c|c|c|}
\hline \multirow[b]{2}{*}{ Variabel } & \multicolumn{4}{|c|}{ Total Sampel } & \multicolumn{2}{|c|}{ Jawa } & \multicolumn{3}{|c|}{ Luar Jawa } \\
\hline & $\begin{array}{l}\text { Odd } \\
\text { Ratio }\end{array}$ & $\mathrm{z}$ & $\mathrm{P}>|\mathrm{z}|$ & $\begin{array}{l}\text { Odd } \\
\text { Ratio }\end{array}$ & $\mathrm{z}$ & $\mathrm{P}>|\mathrm{z}|$ & $\begin{array}{l}\text { Odd } \\
\text { Ratio }\end{array}$ & $\mathrm{z}$ & $\mathrm{P}>|\mathrm{z}|$ \\
\hline Umur (Tahun) & 0,991 & $-1,21$ & 0,225 & 0,992 & $-0,83$ & 0,407 & 0,988 & $-1,03$ & 0,302 \\
\hline Pria (dummy) & 1643 & 1,68 & $0,093^{*}$ & 1,973 & 1,57 & 0,116 & 1,347 & 0,67 & 0,505 \\
\hline Menikah (dummy) & 0,563 & 2,16 & $0,030^{* *}$ & 0,786 & $-0,70$ & 0,484 & 0,347 & 2,42 & $0,016^{* *}$ \\
\hline $\begin{array}{l}\text { Jumlah Anggota RT } \\
\text { Dewasa (Org) }\end{array}$ & 1,111 & 2,57 & $0,010^{* *}$ & 1,102 & 1,65 & $0,098^{*}$ & 1,119 & 1,88 & $0,060^{*}$ \\
\hline $\begin{array}{l}\text { Jumlah Anggota } \\
\text { Keluarga (Org) }\end{array}$ & 0,988 & $-0,39$ & 0,699 & 1,004 & 0,09 & 0,927 & 0,972 & $-0,70$ & 0,485 \\
\hline $\begin{array}{l}\text { Lama Pendidikan } \\
\text { (thn) }\end{array}$ & 1,100 & 5,47 & $0,000^{* * *}$ & 1,129 & 4,91 & $0,000^{* * *}$ & 1,072 & 2,76 & $0,006^{* * *}$ \\
\hline $\begin{array}{l}\text { Status Kepemilikan } \\
\text { Lahan (Dummy) }\end{array}$ & 1,447 & 2,54 & $0,011^{* *}$ & 1,307 & 1,38 & 0,169 & 1,730 & 2,43 & $0,015^{* *}$ \\
\hline Log Luas Lahan & 1,220 & 3,51 & $0,000^{* * *}$ & 1,291 & 3,32 & $0,001^{* * *}$ & 1,116 & 1,35 & 0,176 \\
\hline Log Harga & 1,507 & 1,26 & 0,207 & 1,932 & 1,34 & 0,180 & 1,182 & 0,39 & 0,699 \\
\hline Irigasi (dummy) & 0,914 & $-0,61$ & 0,544 & 0,993 & $-0,03$ & 0,973 & 0,801 & $-0,98$ & 0,329 \\
\hline $\begin{array}{l}\text { Penyuluhan } \\
\text { (dummy) }\end{array}$ & 0,785 & 1,67 & $0,095^{*}$ & 0,594 & 2,66 & $0,008^{* * *}$ & 1,074 & 0,34 & 0,733 \\
\hline Desa (dummy) & 0,782 & $-0,89$ & 0,371 & 1,001 & 0,00 & 0,998 & 0,748 & $-1,05$ & 0,296 \\
\hline Jawa (dummy) & 0,720 & $-1,08$ & 0,280 & & & & & & \\
\hline Desa_Jawa (dummy) & 1,230 & 0,62 & 0,537 & & & & & & \\
\hline Konstanta & 0,001 & $-2,41$ & $0,016^{* *}$ & 0,0004 & $-2,43$ & $0,015^{* *}$ & 0,050 & $-0,84$ & 0,402 \\
\hline Pseudo R2 & & & & & & & & & 64 \\
\hline Wald Chi2 & & & & & & & & & 20 \\
\hline $\mathrm{N}$ & & & & & & & & & 11 \\
\hline
\end{tabular}

Taraf signifikansi secara statistik (robust) : ${ }^{* * *} \mathrm{p}<0,01,{ }^{* *} \mathrm{p}<0,05,{ }^{*} \mathrm{p}<0,1$

Sumber: Hasil Olahan Data Primer, 2020

Variabel selanjutnya yang berpengaruh positif dan signifikan secara statistik adalah penyuluhan yang diikuti oleh petani padi. Penyuluh pertanian bagi petani padi merupakan mitra yang sangat berperan dalam kegiatan usahataninya, termasuk dalam kegiatan pemasaran. Penyuluh pertanian dapat menjadi sumber informasi langsung dan penghubung petani dan calon pembeli, disamping itu penyuluh merupakan informan yang dapat memberikan informasi terbaru mengenai teknologi informasi (telepon seluler). Hasil penelitian ini sejalan dengan kajian yang Mittal and Mehar (2012) di India, yang menyebutkan bahwa penyuluh sangat berpengaruh terhadap petani untuk melakukan kegiatan pemasaran dengan menggunakan telepon seluler. Sehingga 
dengan demikian, ke depan peran penyuluh perlu dioptimalkan kembali terutama untuk mendukung pertanian era industri 4.0.

Variabel lain yang diestimasi menunjukkan hasil yang tidak signifikan, diantaranya adalah variabel umur, jumlah anggota keluarga, harga gabah, irigasi, dan dummy wilayah (desa, Jawa dan Ketika petani ada di desa dan di Pulau Jawa). Variabel-variabel ini diduga secara statistik tidak berpengaruh secara signifikan memengaruhi keputusan petani dalam menggunakan telepon seluler untuk kegiatan pemasaran. Namun dari variabel ini dapat diperoleh beberapa informasi, bahwa variabel umur menunjukkan bahwa semakin muda umur petani maka peluang untuk menggunakan telepon seluler semakin besar untuk kegiatan pemasaran (tanda negative untuk koefisien $z$ ). hal ini sesuai dengan fenomena yang ada bahwa generasi milenieal lebih adaptif dalam menggunakan perangkat gawai dalam kehidupan sehari-hari, termasuk di perdesaan dan pertanian. Variabel jumlah anggota keluarga bertanda negative menunjukkan bahwa semakin kecil ukuran rumah tangga akan mendorong petani untuk menggunakan telepon selulernya. Hal ini dimungkinkan karena ukuran rumah tangga yang lebih kecil berimplikasi pada pengeluaran rumah tangga yang lebih kecil, sehingga alokasi dana untuk pembelian paket data internet telepon seluler dapat dilakukan. Variabel koefisien memberikan pengaruh negatif, yang memiliki arti bahwa petani yang sawahnya tidak dialiri irigasi lebih besar peluangnya untuk menggunakan telepon untuk kegiatan pemasaran. Sementara itu variabel dummy wilayah (desa, Jawa dan interaksi desa Jawa) tidak berpengaruh secara statistik bagi petani menggunakan telepon selulernya untuk kegiatan pemasaran. Hal ini diduga bahwa sebagian besar masyarakat di perdesaan telah memilki telepon seluler, namun tidak semua dapat mengakses internet dan menggunakannya untuk kegiatan yang lebih produktif (Subiakto, 2013).

Analisis disagreasi dilakukan untuk melihat faktor-faktor yang memengaruhi keputusan petani mennggunakan telepon selulernya untuk kegiatan pemasaran. Berdasarkan Tabel 2, jumlah petani yang menjadi sampel dalam kajian ini di Pulau Jawa sebanyak 916 rumah tangga, sementara di luar Pulau Jawa sebanyak 641 rumah tangga. Berdasarkan hasil analisis, dapat dilihat keputusan petani di Pulau Jawa dalam menggunakan telepon seluler untuk kegiatan pemasaran dipengaruhi (positif dan signifikan) oleh jumlah anggota rumah tangga dewasa, pendidikan, luas lahan, dan program penyuluhan yang diikuti petani. Sementara itu, faktor-faktor yang memengaruhi keputusan petani di luar Pulau Jawa menggunakan telepon seluler untuk kegiatan pemasaran secara positif dan signifikan adalah status pernikahan, jumlah anggota rumah tangga dewasa, tingkat pendidikan dan status kepemilikan lahan.

Hasil estimasi pada Tabel 2, menunjukkan bahwa variabel pendidikan memberikan pengaruh yang positif dan siginifikan secara statistik untuk semua model analisis. Hal ini mengindikasikan bahwa pendidikan menjadi faktor 
penting yang mampu memberikan penagruh kepada petani agar dapat menggunakan telepon selulernya untuk dimanfaatkan pada kegiatan produktif, salah satunya kegiatan pemasaran. Tingkat pendidikan yang lebih baik, mampu membuka wawasan berpikir dan tetap mendorong petani untuk mampu belajar dan meningkatkan keterampilan. Sehingga dengan demikian perlu dirancang program pendidikan formal dan non formal bagi petani, khususnya generasi muda agar mempercepat evolusi teknologi informasi pada bisnis pertanian (Ferrer et al., 2003).

\section{Dampak Penggunaan Telepon Seluler untuk Kegiatan Pemasaran Hasil Pertanian}

Dampak penggunaan telepon seluler untuk kegiatan pemasaran hasil pertanian padi pada bagian ini menggunakan teknik analisis Propensity Score Matching (PSM). Pada tahap awal teknik analisis PSM melakukan standarisasi atau covariate balance (Lampiran 1), setelah itu membandingkan kelompok treatment (menggunakan telepon seluler untuk pemasaran) dan kelompok kontrol (tidak menggunakan telepon seluler untuk pemasaran) pada data awal. Pada Gambar 1, menunjukkan balance plot dapat dilihat bahwa kelompok treatment dan kontrol memiliki perbedaan yang cukup nyata (grafik bagian kiri). Kondisi ini menunjukkan bahwa kedua kelompok tidak memiliki kesamaan pencocokan (equal match), dan apabila membandingkan keduanya secara langsung akan memberikan kesimpulan yang tidak tepat karena bias. Sehingga perlu dilakukan pencocokan (match) antar kelompok, sehingga akan tampak karakteristik yang dimiliki kedua kelompok mendekati kondisi yang 'benarbenar' sama (Gambar 1 bagian kanan). Sehingga demikian, model PSM setelah proses pencocokan pada kedua kelompok yang matched meyakinkan bahwa perbedaan penerimaan usahatani yang menjadi indicator outcome antar kedua kelompok disebabkan oleh penggunaan telepon seluler.

Agar penarikan kesimpulan dapat dilakukan dengan benar maka digunakan model PSM dengan pendekatan Nearest Neighbour Matching dan Kernel Matching, sehingga dapat mengurangi potensi bias yang terjadi saat estimasi. Berdasarkan Tabel 3, menunjukkan bahwa rata-rata bias yang terjadi pada raw data berdasarkan metode Nearest Neighbour Matching sebesar $10.578,28$ dan koreksi bias terkecil yang telah dilakukan pada model ini adalah 3.720.408 dan nilai koreksiterbesar adalah 10.200.000. Metode tersebut dapat meminimalkan perbedaan estimated propensity score antara kelompok petani yang menggunakan telepon seluler dan kelompok petani yang tidak menggunakan telepon seluler untuk kegiatan pemasaran. Sedangkan, jika berdasarkan metode Kernel Matching kelompok petani yang menggunakan telepon seluler untuk pemasaran (kelompok treatment) dicocokkan dengan bobot rata-rata tertimbang dari petani yang tidak menggunakan telepon seluler untuk kegiatan pemasaran (kelompok control). Hasil menunjukkan bahwa rata-rata bias pada raw data 
sebesar -235.998,90 dan koreksi bias yang telah dilakukan sebesar 5.413.948 (koreksi bias terkecil) dan koreks bias terbesar adalah 10.800.000.

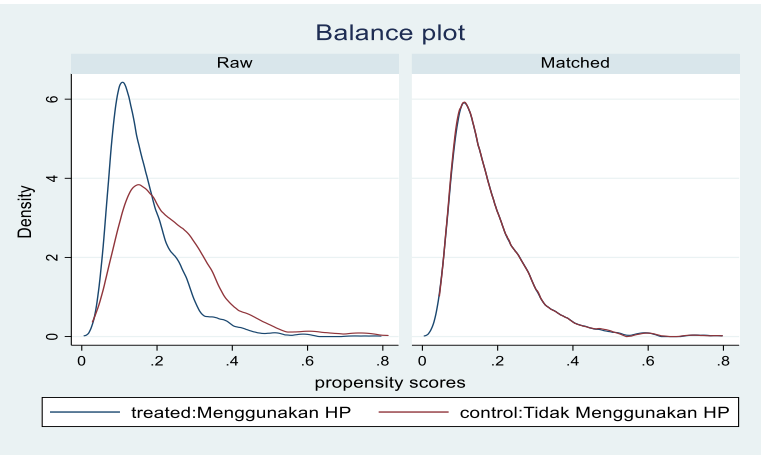

Gambar 1

Balance Plot Sebelum dan Sesudah Dilakukan Matching

(Sumber: Hasil Olahan Data Primer, 2020)

Tabel 3 Koreksi Bias dengan Menggunakan Pendekatan Nearest Neighbour Matching dan Kernel Matching

\begin{tabular}{lcrr}
\hline \multicolumn{1}{c}{ Metode } & Observed & \multicolumn{1}{c}{ Bias } & \multicolumn{1}{c}{\begin{tabular}{c}
\multicolumn{1}{c}{ Koreksi Bias } \\
(95\% Conf.Interval)
\end{tabular}} \\
\hline Nearest Neighbour Matching & 6.778 .694 & $10.578,28$ & $3.720 .408-10.200 .000$ \\
Kernel Matching & 7.426 .080 & $-235.998,90$ & $5.413 .948-10.800 .000$ \\
\hline
\end{tabular}

Sumber: Hasil Olahan Data Primer, 2020

Hasil dampak penggunaan telepon seluler untuk kegiatan pemasaran oleh petani padi yaitu terhadap rata-rata penerimaan usahatani diperlihatkan pada Tabel 4. Berdasarkan metode Nearest Neighbour Matching, terdapat kelompok kontrol sebanyak 223 yang matched yang digunakan oleh model untuk diestimasi. Nilai Average Treatment on Treated (ATT) pada model Nearest Negbhbour Matching sebesar 6.780.000 dan signifikan secara statistik (T-stat = 5,34 atau signifikan untuk tingkat kepercayaan 95 persen). Hal ini menunjukkan bahwa petani yang menggunakan telepon seluler untuk kegiatan pemasaran mampu meningkatkan penerimaan petani padi sebesar Rp. 6.780 .000 per tahun, bila dibandingkan dengan rata-rata penerimaan petani yang tidak menggunakan telepon selulernya untuk kegiatan pemasaran. Hasil yang sama juga ditunjukkan oleh PSM dengan pendekatan Kernel Matching, pendekatan ini menunjukkan bahwa tidak ada responden yang hilang karena proses pencocokan, dapat dilihat bahwa jumlah petani kontrol dan treatment sama dengan data awal, yakni masing-masing sebanyak 276 dan 1.281. Nilai ATT pada model Kernel Matching menunjukkan nilai 7.430.000 dan signifikan (T-stat = 5,45 atau siginikan tingkat kepercayaan 95 persen). Pada model ini dampak rata-rata penerimaan petani yang menggunakan telepon seluler lebih besar yakni Rp.

36 | Feryanto dan Nia Rosiana; Penggunaan Telepon Seluler ... 
7.430.000 per tahun bila dibandingkan dengan penerimaan petani yang tidak menggunakan telepon seluler untuk kegiatan pemasarannya.

Tabel 4 Dampak Evaluasi Penggunaan Telepon Seluler Pada Aktivitas Pemasaran Petani Padi

\begin{tabular}{lccccc}
\hline \multicolumn{1}{c}{ Metode } & $\begin{array}{c}\text { Jumlah Petani } \\
\text { yang } \\
\text { Menggunakan } \\
\text { Telepon Seluler } \\
\text { (Treatment) }\end{array}$ & $\begin{array}{c}\text { Jumlah Petani } \\
\text { yang Tidak } \\
\text { Menggunakan } \\
\text { Telepon Seluler } \\
\text { (Control) }\end{array}$ & ATT & $\begin{array}{c}\text { Standard } \\
\text { Error } \\
\text { (SE) }\end{array}$ & t-statistics \\
\hline $\begin{array}{l}\text { Nearest Neighbour } \\
\text { Matching }\end{array}$ & 276 & 223 & 6.780 .000 & 1.560 .000 & $5,34^{* *}$ \\
Kernel Matching & 276 & 1.281 & 7.430 .000 & 1.360 .000 & $5,45^{* *}$ \\
\hline
\end{tabular}

Ket : signifikan pada tingkatkepercayaan (level of confidence) $95 \%(p$-value $=0.05)$

Sumber: Hasil Olahan Data Primer, 2020

Hasil model PSM menunjukkan bahwa penggunaan telepon seluler oleh 10,7 persen atau 276 dari 1.557 petani memberikan dampak positif dilihat dari penerimaan usahatani selama satu tahun. Hal ini sejalan dengan beberapa penelitian sebelumnya yang menunjukkan bahwa petani yang adaptif dan menggunakan telepon selulernya untuk mendukung kegiatan usahataninya akan mampu mengurangi asimetri informasi, membuka peluang pasar yang lebih luas, mendapatkan informasi lebih cepat dan mampu dalam jangka panjang mampu meningkatkan kesejahterannya (Lio and Liu, 2006; Jensen, 2010; Fafchamps and Minten, 2012; Mittal dan Mehar, 2012; Khan et al., 2019). Merujuk dari data Kemkominfo (2015) yang menunjukkan bahwa petani yang memiliki dan mengakses teknologi informasi dan komunikasi hanya 7,2 persen perlu mendorong dan melakukan sosialisasi serta pendampingan untuk memberikan pemahaman penggunaan telepon seluler di petani. Hal ini dapat dikaitkan kepada peran penyuluhan dan tingkat pendidikan yang memiliki pengaruh bagi petani untuk menggunakan telepon seluler dalam aktivitas pemasaran hasil pertanian. Sehingga dengan demikian, akan semakin banyak petani yang menggunakan telepon selulernya untuk kegiatan produktif dalam proses pengambilan keputusan dan kegiatan pemasaran hasil pertanian.

\section{SIMPULAN DAN SARAN}

\section{Simpulan}

Berdasarkan hasil dan pembahasan pada penelitian, kesimpulan yang dapat diambil adalah sebagai berikut;

1. Kegiatan pemasaran petani yang menggunakan telepon seluler dipengaruhi beberapa faktor diantaranya adalah jenis kelamin, status pernikahan, jumlah 
anggota rumah tangga dewasa, pendidikan, status kepemilikan lahan, luas lahan, dan penyuluhan.

2. Penggunaan telepon seluler untuk kegiatan pemasaran hasil pertanian menunjukkan dampak positif dan signifikan terhadap kinerja usahatani dimana, petani yang menggunakan telepon seluler (kelompok treatment) untuk kegiatan pemasaran mendapatkan rata-rata penerimaan usahatani yang lebih besar bila dibandingkan petani yang tidak menggunakan telepon selulernya sebagai media pemasaran (kelompok kontrol).

\section{Saran}

Tingkat pendidikan memberikan pengaruh signifikan kepada petani untuk menggunakan telepon selulernya dalam kegiatan pemasaran pada seluruh model (total sampel dan dis-agregasi berdasarkan pulau Jawa dan luar Jawa). Hal ini mengindikasikan bahwa pendidikan petani harus menjadi yang perhatian utama, terutama generasi muda pertanian agar tertarik mengusahakan sektor pertanian menggunakan teknologi informasi dan komunikasi dengan demikian transformasi pertanian dari konvensional ke modern dapat segera tercapai. Masih rendahnya penggunaan dan pemanfaatan telepone seluler ditingkat petani, perlu diimbangi dengan pendampingan mengenai pemanfaatan telepone seluler untuk kegiatan produktif. Hal ini dapat dilakukan melalui program penyuluhan kepada petani langsung, atau melalui anak-anak petani.

\section{DAFTAR PUSTAKA}

[Kemenkominfo] Kementerian Komunikasi dan Informatika, RI. 2015. Pemanfaatan dan Pemberdayaan Teknologi Informasi dan Komunikasi Pada Petani dan Nelayan (Survey Rumah Tangga dan Best Practices).Jakarta: Pusat Peneltian dan Pengembangan Penyelenggaraan Pos dan Informatika, Badan Penelitian dan Pengembangan Sumber Daya Manusia, Kemkominfo. ISBN 978-602-73633-1-1.

Aker, J. C., \& Fafchamps, M. 2013. Mobile phone coverage and producer markets:

Evidence from West Africa. CSAE Working Paper,WPS/2013-09.

Dasli, APE., Muljono, P., \& Susanto, D. 2015. Pemanfaatan cyber extension melalui telepon genggam oleh petani anggrek di Taman Anggrek Ragunan, Jakarta Selatan. Jurnal Penyuluhan. 11(2), 103-115. https://doi.org/10.25015/penyuluhan.v11i2.10574.

Donkor, E., Onakuse, S., Bogue, J., \& Rios-Carmenado, I D. 2018. Determinants of Farmers Participation in Direct Marketing Channels: A Case Study for Cassava in The Oyo State of Nigeria. Spanish Journal of Agricultural Research, 16(2), 1-17. https://doi.org/10.5424/sjar/2018162-12076.

38 | Feryanto dan Nia Rosiana; Penggunaan Telepon Seluler ... 
Etwire, P.M., Buah, S., Ouédraogo, M. et al. 2017. An Assesment of Mobile PhoneBased Dissemination of Weather and Market Information in The Upper West Region of Ghana. Agriculture And Food Security, 6(8), 2-9. https:// doi.org/10.1186/s40066-016-0088-y.

Fafchamps, M., \& Minten, B. 2012. Impact of SMS-Based Agricultural Information on Indian Farmers. The World Bank Economic Review, 26(3),383-414.

Ferrer, SRD., Schroder, DH., \&Ortmann, GF. 2003. Internet Use and Factors Affecting Adoption of Internet Applications by Sugarcane Farm Businesses in The Kwazulunatal Midlands. EconsPapers, The 41 st Annual Conference of the Agricultural Economic Association of South Africa (AEASA). https://doi.org/10.22004/ag.econ.19078.

Getler, Paul J., Martinez, S., Premand, P., et al. (011. Impact Evaluation in Practice. Washington D.C: The World Bank.

Holden, S., Shiferaw, B., \& Pender, J. 2001. Market Imperfections and Land Productivity in the Ethiopian Highlands. Journal of Agricultural Economics, 52(3), 53-70. https://doi.org/10.1111/j.1477-9552.2001.tb00938.x.

Jensen, R. 2007. The Digital Provide: Information (Technology), Market Performance and Welfare in The South Indian Fisheries Sector. Quarterly Journal of Economics, 122(3),879924.https://doi.org/10.1162/qjec.122.3.879.

Jensen, R. 2010. Information, Efficiency and Welfare in Agricultural Market. Agricultural Economics, 41(S1), 203-216. https://doi.org/10.1111/j.15740862.2010.00501.x.

Khan, Nassir Abbas., Qijie, Q., Ali, S., Shabaz, B., \& Shah, A.A. 2018. Farmer's Use of Mobile Phone for Accessing Agricultural Information in Pakistan: A Case of Punjab Province. Ciencia Rural, 49(10), 1-2. https://doi.org/10.1590/0103-8478cr20181016.

Khandker, Shaidur R., Koolwal, Gayatri B., \& Samad, Hussain A. 2010. Handbook on Impact Evaluation: Quantitative Methods and Practices. Washington D.C: The World Bank.

Lio, M., \& Liu, M. 2006. ICT and Agricultural Productivity: Evidence from CrossCountry Data. Agricultural Economics, 34(3), 221-228. https://doi.org/10.1111/j.1574-0864.2006.00120.x.

Mittal, S., \& Mehar, M. 2012. How Mobile Phone Contribute to Growth of Small Farmers? Evidence from India. Quarterly Journal of International Agriculture, 51(3), 227-244. https://doi.org/10.22004/ag.econ.155478.

Prayoga, K. 2017. Pemanfaatan Media Sosial Dalam Penyuluhan Pertanian dan Perikanan di Indonesia. Agroekonomika, 6(1), 32-44. https://doi.org/10.21107/agriekonomika.v6i1.2680.

Soedarto, T., dan H, Hendrarini. 2019. Pengembangan Perilaku Petani Dalam Mewujudkan Ketahanan Pangan Rumah Tangga Berbasis Teknologi 
Informasi di Kabupaten Bangkalan Madura. Jurnal Teknologi Informasi dan Komunikasi. 17(2),45-48. https://doi.org/10.33005/scan.v14i2.1486.

Strauss, Jhon et al. 2015. User's Guide for the Indonesia Family Life Survey, Wave 5. Vol.2. RAND Labor and Population Working Paper Series. Retrieved from

https://www.rand.org/content/dam/rand/pubs/working_papers/W R1100/WR1143z2/RAND_WR1143z2.pdf.

Subiakto, H. 2013. Internet Untuk Pedesaan dan Pemanfaatannya Bagi Masyarakat. Masyarakat, Kebudayaan dan Politik.26(4), 243-256. ISSN 20867050.

Sutisna, H. 2018. Pemanfaatan jaringan internet sehat bagi petani untuk kemajuan ekonomi Desa Sukaharja. Jurnal Abdimas BSI. 1(3),406-415. ISSN 2614-6711.

Tadasse, G., \& Bahigwa, G. 2015. Mobile Phones and Farmers' Marketing Decisions in Ethiopia. World Development, 68(2015), 269-307. https://doi.org/10.1016/j.worlddev.2014.12.010.

Warren, M. 2004. Farmers online : drivers and impediments in adoption of internet in UK agricultural businesses. Journal of Small Business and Enterprise Development. 11(3):371-381. ISSN 1462-6004 https://doi.org/10.1108/14626000410551627.

Yuantari, CMG., A, Kurniadi., \& Ngatindriatun. 2016. Pemanfaatan teknologi informasi untuk meningkatkan pemasaran hasil pertanian di Desa Curut Kecamatan Penawangan Kabupaten Grobogan Jawa Tengah. Techno COM. 15(1), 43-47. https://doi.org/10.33633/tc.v15i1.1080.

\section{Lampiran 1 Ringkasan Keseimbangan Kovariasi (Covariate Balance)}

\begin{tabular}{lcccc}
\hline \multirow{2}{*}{ Variabel } & \multicolumn{2}{c}{ Standardized Differences } & \multicolumn{2}{c}{ Variance Ratio } \\
\cline { 2 - 5 } & Raw & Matched & Raw & Matched \\
\hline Umur (Tahun) & $-0,232$ & 0,031 & 1,033 & 1,154 \\
Pria (dummy) & 0,149 & 0,039 & 0,648 & 0,896 \\
Menikah (dummy) & 0,064 & 0,064 & 0,858 & 0,856 \\
JumlahAnggotaKeluarga (Orang) & 0,195 & 0,039 & 0,980 & 0,893 \\
JumlahAnggota RT Dewasa (Orang) & $-0,050$ & 0,074 & 1,053 & 1,047 \\
Lama Pendidikan (Tahun) & 0,486 & 0,001 & 1,229 & 0,922 \\
Status KepemilikanLahan (Dummy) & 0,145 & $-0,033$ & 1,074 & 0,980 \\
Luas Lahan & 0,318 & 0,060 & 1,808 & 0,688 \\
Harga & 0,071 & $-0,045$ & 1,091 & 0,909 \\
Irigasi (dummy) & $-0,007$ & $-0,037$ & 1,002 & 1,001 \\
Penyuluhan (dummy) & $-0,162$ & $-0,008$ & 0,986 & 1,000 \\
Desa (dummy) & $-0,030$ & 0,064 & 1,038 & 0,924 \\
Jawa (dummy) & $-0,181$ & $-0,023$ & 1,047 & 1,008 \\
Desa_Jawa (dummy) & $-0,148$ & 0,0491 & 0,933 & 1,015 \\
\hline
\end{tabular}

40 | Feryanto dan Nia Rosiana; Penggunaan Telepon Seluler ... 